G. Efendiyev ${ }^{1}$, Dr. Sci. (Techn.), Prof., Corr. Member of ANAS, E-mail: galib_2000@yahoo.com, M. Karazhanova², PhD (Techn.),

E-mail: mikado_70@inbox.ru; D. Akhmetov ${ }^{2}$, PhD student, E-mail: aldee@list.ru;

I. Piriverdiyev ${ }^{1}, \mathrm{PhD}$ student,

E-mail: igorbaku@yandex.ru;

1 Institute of Oil and Gas Azerbaijan of National Academy of Sciences,

9 F. Amirov Str., Baku, AZ1000, Azerbaijan;

${ }^{2}$ Yessenov University,

32 microdistricts, Aktau, 130003, The Republic of Kazakhstan

\title{
EVALUATING THE DEGREE OF COMPLEXITY OF TIGHT OIL RECOVERY BASED ON THE CLASSIFICATION OF OILS
}

\begin{abstract}
(Представлено іноземним членом редакційної колеаії проф. Г. Кулієвим)
The article discusses the results of the use of cluster analysis in assessing the degree of oil recovery complexity and its impact on the performance indicator. For this purpose, clustering was performed using a fuzzy cluster analysis algorithm. It should be noted that along with the deposits of heavy and highly viscous oils, a large share of hard-to-recover reserves is also confined to conditions with very low reservoir permeability values. Data on viscosity, oil density and oil permeability of in-situ conditions from various fields of Kazakhstan are collected. Using the results of this classification, a statistical analysis of indicators of various types of hard-torecover oils was performed. In the process of analysis, a generalized characteristic was determined for each class of oil, including viscosity, oil density and reservoir permeability. The generic characteristic is a linear transformation of the three characteristics. The results were subjected to statistical processing. At the same time, an attempt was made to establish and analyze the relationship between the degree of recovery complexity of hard-to-recover oils and oil recovery coefficient. In the course of the analysis, the average values of the oil recovery coefficient and the index of the degree of recovery complexity of hard-to-recover oil within each cluster were calculated and the relationship between them was plotted. The observed dependence, built on averaged points, is close to a power law, and, as one would expect, with an increase in the degree of oil recovery complexity, the oil recovery coefficient falls. The obtained estimates of the degree of oil recovery complexity allow us to rank different types of oils by their viscosity, density and reservoir permeability, which can be used to compare types of hard-to-recover oils by the value of the quality indicator. Methods to solve the problem of hard-to-remove high-viscosity and heavy oils should be aimed at reducing the viscosity of oil in the reservoir:
\end{abstract} injection of hot water/steam into the reservoir, the use of electric heaters, etc.

Purpose. Assessment of the degree of oil recovery complexity and its impact on the efficiency of field development.

The technique. The solution of the tasks set in the work was carried out on the method of mathematical statistics and the theory of fuzzy sets. In this case, the methods of processing the results, the correlation analysis, and the algorithm of fuzzy cluster analysis were used.

Results. As a result of studies, 4 classes were obtained, each of which characterizes the degree of oil recovery complexity, a parameter was proposed for quantifying the degree of complexity, including oil density and viscosity, reservoir permeability, a relationship between this parameter and oil recovery coefficient was obtained.

Scientific novelty. A classification of hard-to-recover reserves based on a fuzzy cluster analysis has been performed, and a parameter has been proposed for quantifying the degree of oil recovery complexity, a relationship has been obtained that allows judging the oil recovery by the degree of oil recovery complexity.

Practical significance. The results obtained make it possible to classify hard-to-recover reserves and make decisions on the choice of methods for influencing the reservoir in various geological conditions.

Keywords: density, viscosity, permeability, fuzzy cluster, hard-to-recover reserves, degree of recovery complexity, oil recovery.

Introduction. The oil industry has now reached a stage when oil fields are being developed under increasingly unfavorable conditions due to reserves deterioration and a greater share of hard-to-recover (HTR) reserves. Large number of prolific pools and fields are mature and plagued by declining oil production and increasing water cut as well as unfavorable qualitative characteristics of crude oil reserves in pools that are once again brought on stream $(\mathrm{AH}-$ тониади и Савенок, 2013; Нвизуг-Би и Савенок, 2015; Ященко и Полищук, 2016).

In order to give a clear and exhaustive definition of what HTR reserves actually are, we need to analyze undeveloped oil reserves and understand the reasons why they do not contribute much to oil production. Among these reasons are physical and chemical oil properties, description of settings in which oil occurs and so on. In other words, the term 'HTR reserves' becomes applicable when there is a discrepancy between available technological solutions and geological aspects of crude oil occurrence as well as oil properties.

Thus, hard-to-recover reserves are reserves concealed in pools (fields, development units) whose geological settings of oil occurrence and (or) physical oil properties are relatively unconducive to oil recovery and whose development with existing technologies under the current tax system is regarded as economically non-viable. The term 'hard-to-recover reserves' has been applied very loosely because reserves can vary in the complexity of their recovery. There is, therefore, a need to classify them and evaluate the degree of recovery complexity. There is a wide variety of object classifying techniques to select from. Before applying a certain technique, we need to substantiate our choice of classification criteria. Numerous studies are consistent with factors that are responsible for the complexity of oil recovery, i.e. indicators that determine oil properties and settings in which oil occurs.

We also examined the results of HTR reserves classification and revealed a need for dividing the whole set into homogeneous groups according to a combination of classification criteria. A cluster analysis is best suited for this task (Efendiyev et al., 2018). In order to substantiate the technique of choice this paper discusses the core concept of the cluster analysis and the results of its application, and evaluates the degree of oil recovery complexity and its effect on performance.

The results are produced by applying clustering techniques in examining geotechnical data. Over the recent years, the issues of cluster analysis (sometimes also known as the issues of automated classification) have been used extensively in such spheres as economics, sociology, medicine, geology, oilfield development and other industries, where we deal with sets of objects of arbitrary nature described as $x=\left\{x_{1}, x_{2}, \ldots, x_{N}\right\}$ vectors that have to (c) Efendiyev G., Karazhanova M., Akhmetov D., Piriverdiyev I., 2020 
be automatically divided into groups of homogeneous objects according to the criteria of similarities (within a homogeneous object or a cluster) and differences between these objects. Much has been published on psychological, sociological, economic, G\&G, well drilling, oil and gas field development studies (Akhmetov et al., 2018; Koilybayev et al., 2018; Зайченко и Гончар, 2007).

As previously noted in different publications, there are more than a hundred of different clustering algorithms, e.g. hierarchical and non-hierarchical cluster analyses and fuzzy clustering.

In recent years, these techniques have been widely applied for collecting and processing data and mining intellectual knowledge from data. Conventional cluster analysis techniques are based on a clear-cut partition of an initial set into several subsets. Each point (recognizable object) belongs to one cluster only, i.e. the characteristic function (the equivalent of a membership function in conventional sets) amounts to one for this cluster and to zero for the other clusters. If a point does not belong to any cluster, then a new cluster is created. However, such a restriction is not always true. More often than not partition must be done in such a way as to determine the degree to which each object belongs to each set. In this case, it makes sense to use fuzzy methods of cluster analysis. Fuzzy cluster analysis in particular and cluster analysis in general (also known as automated classification) have been extensively used over the last years in economics, sociology, medicine, geology, oil field development and other industries, where we deal with sets of objects of arbitrary nature described as $x=\left\{x_{1}, x_{2}, \ldots, x_{n}\right\}$ vectors that have to be automatically broken down into groups of objects that are homogeneous in regards to specific criteria. Recent years have seen these techniques being widely applied for the purpose of data acquisition and analysis. As mentioned above, conventional cluster analysis techniques are based on a clear-cut partition of an initial set into subsets, and each point can only be assigned to one cluster. Roughly speaking, clustering means dividing a set of input indicators (vectors) into groups or clusters that are homogeneous in terms of the degree of their 'similarity' and heterogeneous in relation to each other. In other words, each cluster represents a group that contains homogeneous data (selected according to certain clustering criteria), but separate clusters (groups) are heterogeneous with respect to each other.

Thus, a cluster can be defined as a group of elements that share common properties and similar values of classification criteria.

The following two indicators can be regarded as a cluster's characteristics:

- internal homogeneity;

- external isolation, i.e. heterogeneity in relation to other such clusters.

The method elaborated in (Efendiyev et al., 2018) is based on a fuzzy cluster analysis and allows predicting lost circulation of any scale at an early stage of drilling operations. A total of five classes were differentiated in the course of this study, with each class defining the severity of lost circulation expressed as linguistic variables. This provided a basis for building fuzzy models that represent a relationship between the estimates of petrophysical properties and the volume of lost drilling mud. The results obtained facilitate decision-making regarding lost circulation prevention and a timely response to eliminate its consequences. In most cases, specifically when it comes to oilfield practices (Efendiyev et al., 2018; Akhmetov et al., 2018; Koilybayev et al., 2018; Зайченко и Гончар, 2007; Bezdek et al., 1984), a partition must be done in such a way as to determine the degree to which each object belongs to, i.e. the degree of recognition. In this case, it makes sense to opt for fuzzy cluster analysis methods. The application of the $\mathrm{K}$-means technique in classifying seismic data is discussed in (Zhang, 2015). The essence of the problem was as follows. The available seismic data were to be divided into different classes or clusters and analyzed in such a way as to ensure that further production costs will be decreased, new oil-saturated beds will be discovered and the decisions already taken will be scientifically grounded. It is emphasized that the K-means algorithm is suitable for clustering massive datasets and has been used for clustering data collected during exploration. However, the authors note that in this case it is necessary to identify the k-means algorithm for the purpose of seismic data clustering. This work is aimed at improving the conventional $\mathrm{K}-\mathrm{means}$ algorithm and establishing whether it can be successful in examining legacy geological data. It has been proven that by improving the K-means algorithm we can enhance efficiency and feasibility. The article provides an overview of the core theory behind the data mining techniques and discusses the key principles and algorithms of cluster analysis. Seismic data interpretation using cluster analysis techniques is discussed in an article (Sabet and Javaherian, 2009), which says that we can extract more information about the structures and geology of subsurface blocks by clustering seismic data. The paper singles out the efficient K-means clustering algorithm as the clustering technique of choice for classifying seismic facies based on seismic data. By giving the $k$ value (i.e. the number of clusters), the k-means clustering algorithm uses an iterative algorithm that minimizes the sum of distances from each sample to its cluster centroid over all clusters. This algorithm moves samples between clusters until the sum cannot be decreased any further. The results is a set of clusters that are as compact and well separated as possible. The authors note that by applying the K-means clustering algorithm to a real dataset it was shown that more seismic facies appear by increasing the $k$ value and this provides useful information about subsurface deposits.

In (Долинський, 2017), the results of the use of cluster analysis in the classification of geological objects are presented. The methods of spatial clustering, as noted in the work, and the spatial classification (selection of objects with given characteristics in the geological body) are performed by the components of the expert system when predicting areas that are promising for oil and gas. The results of the implementation of the algorithms created for this purpose were tested on the data obtained in the course of drilling and seismic exploration within the Sribnen depression located in the zone of the Central Section of the Dnieper-Donetsk depression. Examples of maps obtained from the results of these calculations are presented, which demonstrate the mutual arrangement of the clusters obtained.

For the purpose of classifying HTR reserves we ran clustering using a fuzzy cluster algorithm and gathered data on oil viscosity, oil density and oil permeability in-situ conditions for the following Kazakstan's fields: Karazhanbas, Kalamkas, Tasbulat, Komsomolskoye, Turkmenoi, Aktas, Dolinnoye, Shinzhir, Zhylankabak, Matin, Severnoye Priozernoye, Tabynai, Arystanovskoye, Kamenistoye, Zholdybai, Airankol', Botakhan, Zapadnaya Prorva, Dosmukhambetovskoye, Zaburunye, Vostochny Makat, Yuzhnoye Karatobe, Severnye Buzachi, Zhetibai, and Dunga. The following three indicators were selected for our cluster analysis: oil viscosity, oil density, and reservoir permeability. The fuzzy cluster analysis produced in total four classes, with each class reflecting the degree of oil recovery complexity (Akhmetov et al., 2018):

- the formation is permeable, while the oil is highly viscous and extra heavy; 
- the formation is moderately permeable, while the oil is viscous and heavy;

- the formation is highly permeable, while the oil is of moderate viscosity and density;
- the formation is poorly permeable, while the oil is light and has low viscosity.

The results produced by the cluster analysis are presented in Table 1.

The results from fuzzy cluster analysis using data from Kazakhstan's fields with HTR reserves

Table 1

\begin{tabular}{|c|c|c|c|c|c|c|c|}
\hline PERM, mD & u, MPa*s & $\rho, \mathrm{g} / \mathrm{cm}^{3}$ & $\eta$ & $\mu_{1}$ & $\mu_{2}$ & $\mu_{3}$ & $\mu_{4}$ \\
\hline 531 & 835 & 0,929 & 0,062419 & 0,9179 & 0,0339 & 0,0304 & 0,0178 \\
\hline 166 & 378 & 0,928 & 0,11044 & 0,8965 & 0,0726 & 0,0175 & 0,0134 \\
\hline$\ldots$ & $\ldots$ & $\ldots$ & $\ldots$ & $\ldots$ & $\ldots$ & $\ldots$ & $\ldots$ \\
\hline 517 & 449 & 0,93 & 0,246132 & 0,9991 & 0,0005 & 0,0003 & 0,0001 \\
\hline 567 & 500 & 0,933 & 0,047994 & 0,9997 & 0,0002 & 0,0001 & 0 \\
\hline 54,3 & 1,6 & 0,792 & 0,486552 & 0,0025 & 0,5481 & 0,0043 & 0,4451 \\
\hline 133 & 1,33 & 0,797 & 0,025344 & 0,002 & 0,7663 & 0,0038 & 0,228 \\
\hline$\ldots$ & $\ldots$ & $\ldots$ & $\ldots$ & $\ldots$ & $\ldots$ & $\ldots$ & $\ldots$ \\
\hline 302 & 7,115 & 0,829 & 0,308 & 0 & 0,9994 & 0,0001 & 0,0005 \\
\hline 404 & 11,54 & 0,855 & 0,241 & 0,0001 & 0,9993 & 0,0003 & 0,0004 \\
\hline 363 & 6,45 & 0,835 & 0,296 & 0 & 0,9996 & 0,0001 & 0,0003 \\
\hline 299 & 8,74 & 0,831 & 0,510654 & 0 & 0,9996 & 0,0001 & 0,0003 \\
\hline 2186 & 491 & 0,927 & 0,148263 & 0,4282 & 0,0739 & 0,4636 & 0,0343 \\
\hline 2088 & 25,03 & 0,799 & 0,241 & 0,0275 & 0,0398 & 0,9094 & 0,0233 \\
\hline$\ldots$ & $\ldots$ & $\ldots$ & $\ldots$ & $\ldots$ & $\ldots$ & $\ldots$ & $\ldots$ \\
\hline 1232 & 54 & 0,877 & 0,171497 & 0,0003 & 0,001 & 0,9985 & 0,0002 \\
\hline 1273 & 21,4 & 0,891 & 0,18184 & 0,0005 & 0,0015 & 0,9977 & 0,0002 \\
\hline 81 & 2,08 & 0,73 & 0,102669 & 0 & 0 & 0 & 1 \\
\hline 11 & 3,8 & 0,722 & 0,183775 & 0 & 0 & 0 & 1 \\
\hline$\ldots$ & $\ldots$ & $\ldots$ & $\ldots$ & $\ldots$ & $\ldots$ & $\ldots$ & $\ldots$ \\
\hline 127 & 3,3 & 0,776 & 0,102243 & 0,0015 & 0,2063 & 0,0029 & 0,7893 \\
\hline 10 & 6,55 & 0,783 & 0,51087 & 0,0022 & 0,2804 & 0,0035 & 0,714 \\
\hline 82,37 & 2,4 & 0,785 & 0,010098 & 0,0021 & 0,3894 & 0,0039 & 0,6046 \\
\hline
\end{tabular}

Note. PERM is permeability of the formation, $v$ is dynamic viscosity, $\rho$ is oil density, $\eta$ is the oil recovery factor, and $\mu_{i}$ is a function defining the degree of membership to the i-th cluster.

The work (Akhmetov et al., 2018) gives a graphical representation of boundaries separating classes-terms- sets of oil density, oil viscosity and reservoir permeability. In this case, light oil has density of $700-815 \mathrm{~kg} / \mathrm{m}^{3}$, moderately heavy oil has density of $800-890 \mathrm{~kg} / \mathrm{m}^{3}$; heavy oil has density of $892-910 \mathrm{~kg} / \mathrm{m}^{3}$; and extra heavy oil has density ranging between 910 and $933 \mathrm{~kg} / \mathrm{m}^{3}$ and low viscous is $(0,17-6,9)$ MPa.s; moderately viscous - $(8,6-55) \mathrm{mPa} . \mathrm{s}$; viscous - (55-160) MPa.s; $160 \mathrm{MPa} . \mathrm{s}$ and higher. Concerning permeability they are highly permeable (8402180) $\mathrm{mD}$; permeable $(480-800) \mathrm{mD}$; moderately permeable (130-690) mD; poorly permeable (less than 130) $\mathrm{mD}$. The results produced by the c-means clustering algorithm helped differentiate HTR reserves according to the degree of complexity of their recovery. This algorithm was proposed by an Australian scientist James Bezdek in 1981. Each class is characterized by its own degree, category of recovery complexity. Once these results are available, we can now perform recognition of a certain oil with known properties and geological setting by assigning it to one class or another. Elements within a certain cluster must be close to each other, while individual clusters must be as far apart as possible. Figure 1 gives a 3D representation of how the specified classes are positioned in relation to each other. The axes shown in the figure represent in-situ oil permeability, oil viscosity and density. Identical points indicate the membership of the oil with certain geological setting and properties (expressed by its coordinates) in a homogeneous cluster.

It should be noted that a greater tight oil output observed in the last few years has led to a variety of problems associated with its production. Developing HTR oil reserves such as highly viscous and heavy oil rich in sulfur, resins, heavy metals etc. considerably deteriorates the quality of oil reservoir resulting in a greater adverse effect on the environment (Ященко и Полищук, 2016).
Statistical analysis and evaluating the degree of oil recovery complexity. Recent years have seen an increase in the amount of tight oil refinement. The degree of their recovery is subject not only to anomalous properties of crude oil but also to intricate geological setting in which such oil occurs. These factors dictate the need for an analysis that will produce generalized quantifiable values that define the complexity of tight oil recovery. Aspects of physical and chemical properties and geological setting in which HTR oil occurs are discussed in (Ященко и Полищук, 2016; Максутов и др., 2005; Муслимов, 2016; Лисовский и Халимов, 2009). However, generalized quantifiable values interrelated with fields' production performance has received insufficient study, which hinders the solution of oil production problems in general. In light of this, we examined performance indicators of different types of HTR oils found in Kazakhstan by using the results of their classification discussed above.

The analysis involved determining a generalized characteristic for each differentiated class of oils (Table 1). This characteristic included oil viscosity, oil density and insitu permeability. The generalized characteristic represents a linear transformation of the three factors. The generalized characteristic was initially expressed as:

It follows that

$$
\ln K=\alpha_{1} \ln 10 \mathrm{v}+\alpha_{2} \rho-\alpha_{3} \ln K_{\text {perm }}
$$

$$
K=\frac{(10 v)^{\alpha_{1}} X^{\alpha_{2}}}{K_{\text {perm }}{ }^{\alpha_{3}}}
$$

Here $\alpha_{1}, \alpha_{2}, \alpha_{3}$ are parameters that honour a weight contribution of each examined indicator. Their values are computed using the following expressions:

$$
\begin{aligned}
\alpha_{1} & =\frac{\Sigma \ln 10 v}{\Sigma \ln 10 v+\Sigma \rho+\Sigma \ln K_{\text {perm }}} \\
\alpha_{2} & =\frac{\Sigma \rho}{\Sigma \ln 10 v+\Sigma \rho+\Sigma \ln K_{\text {perm }}} \\
\alpha_{3} & =\frac{\Sigma \ln K_{\text {perm }}}{\Sigma \ln 10 v+\Sigma \rho+\Sigma \ln K_{\text {perm }}}
\end{aligned}
$$

$K_{\text {perm }}$ is in-situ permeability, $\nu, \rho$ is oil viscosity and density, respectively, $X=e^{\rho}$. 


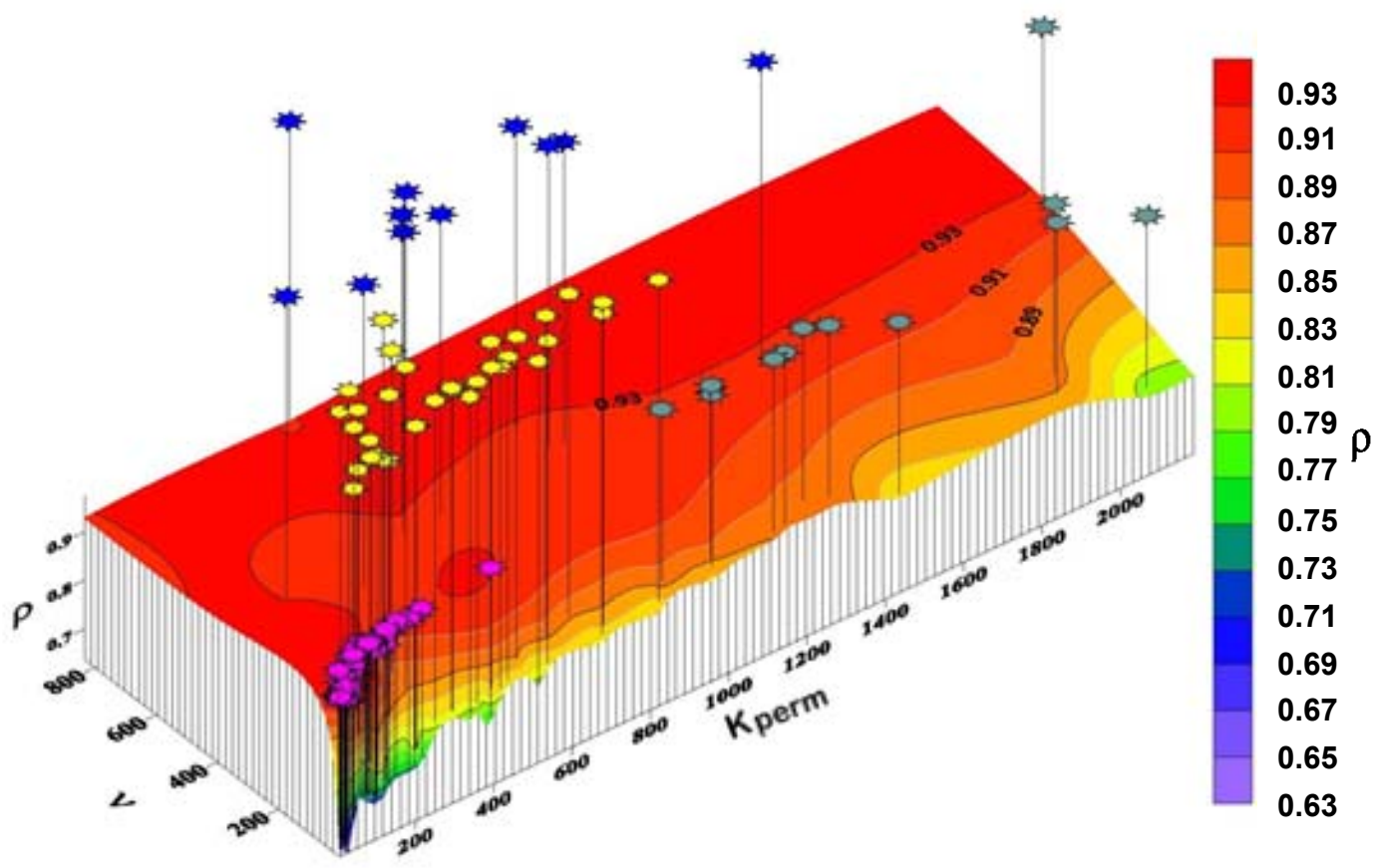

Fig. 1. The position of clusters (defining the degree of oil recovery complexity) in the 3D space

The results were subjected to statistical processing and an attempt was made to establish a relationship between the degree of complexity of tight oil recovery $(\mathrm{K})$ and the oil recovery factor. The analysis involved computing average oil recovery factor values and the estimated degree of tight oil production complexity inside each cluster and generating a relationship between them.

Fig. 2 shows a relationship between oil recovery factor and description of the degree of oil recovery complexity.

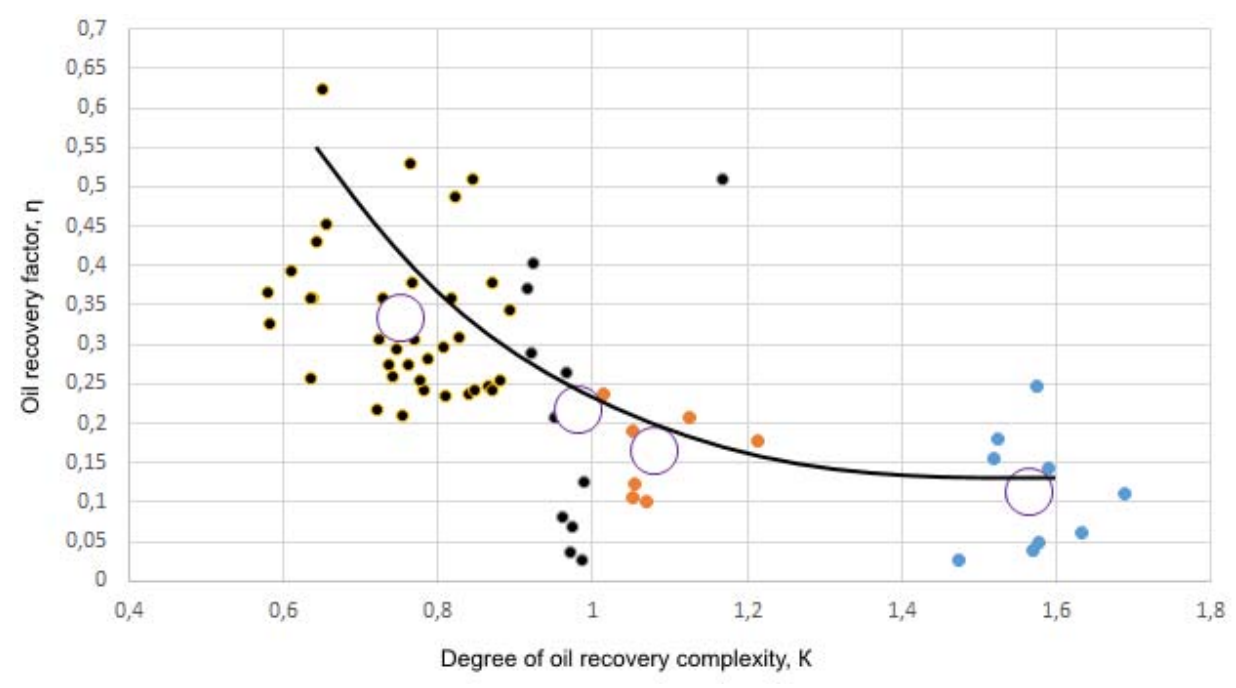

Fig. 2. A relationship between oil recovery factor and description of the degree of oil recovery complexity

The largest signs indicate the points that characterize average values for analogous signs. As seen in Fig. 2, the established relationship constructed on averaged points shows a good match with the power-law relation. As the degree of oil recovery complexity rises, the oil recovery factor unsurprisingly decreases. The observed dependence was built according to the mean values of the studied variables for each cluster. Analytically, this relationship is as follows:

$$
\eta=0,1729 K^{-1.05}
$$

The analysis of this dependence showed that it can be traced quite clearly at the middle points, and the analysis of the correlation coefficients of individual linear sections showed that, with the exception of the first cluster, the links within the other clusters are very weak, and at the same time this approach, complementing the results of clustering, makes it possible to specify the boundaries of homogeneous groups (clusters). Such an approach based on the analysis of the values of the correlation coefficient using the example of the relationship between acoustic impedance and clay content in relation to the differentiation of clay rocks by the porosity was proposed in (Вижва та ін., 2018). The results of applying this approach allow to expand the possibility of statistical methods in solving geological and technological problems.

Conclusion. The following problems arise in developing tight oil reserves: low mobility of oil in reservoir, problems associated with bringing crude oil to the surface and its further transportation due to high oil viscosity and density, which in turn requires heavy expenditure on specialized costly technology and equipment.

By examining the methods and principles of the HTR reserves classifications proposed, we have scientifically substantiated the key concepts underlying the generation and 
practical application of an approach to classifying oil, oil-and-gas, and gas fields according to a set of indicators. This technique enables us to evaluate the degree of oil recovery complexity.

The presented classification of fields with HTR reserves is based on examining and summarizing information about a combination of indicators characterizing the subsurface within several Kazakhstan's fields using a fuzzy cluster analysis algorithm.

The results of this classification have shown that a large share of HTR reserves is confined not only to heavy and high-viscosity oil fields, but also to reservoirs with very low permeability, that is why permeability was included among the classification indicators.

Qualitative aspects of tight oil varying in viscosity, density and occurrence were examined with the proposed criterion of oil quality (tentatively referred to as the degree of oil recovery complexity). We have found a reciprocal relationship between this criterion and the results of tight oil classification, according to which different oils were divided into four classes of quality. We constructed a crossplot between the oil recovery factor and the distinguished characteristics.

The obtained estimates of the degree of oil recovery complexity enable us to rank different types of oil by their viscosity, density and in-situ permeability. This could be useful in comparing the types of tight oils according to the magnitude of the quality indicator.

The approaches to tackling tight high-viscosity and heavy oil issues should be aimed at decreasing oil viscosity in the formation by injecting hot water/steam into the formation, applying electric heaters and so on.

Moreover, it is common knowledge that at a mature stage of field development wells tend to have low production rates and high water cut. Some of these low-yield wells with high water cut are loss-making while some economic producing wells are often idle waiting for well servicing, which in general adversely affects the company's efficiency. In view of the above mentioned, we can conclude that there is a need for a thorough analysis of fields' historical performance and an assessment of well stock efficiency so that we can make the most informed and grounded decisions in future.

\section{Список використаних джерел}

Антониади, Д.Г., Савенок О.В. (2013). Анализ структуры трудноизвлекаемых запасов и тенденций увеличения темпа прироста. ГеоИнжинирине, 18, 2, 76-80.

Вижва, С., Соловйов, І., Круглик, В., Лісний, Г. (2018). Прогнозування зон підвищеної пористості у глинистих породах сходу України. Вісник Київського національного університету. Геологія, 80, 1, 33-39.

Долинський, І. (2017). Геоінформаційний експертно-моделюючий комплекс дослідження регіональних моделей в геології. Вісник Київського національного університету. Геологія, 79, 4, 86-91.

Зайченко, Ю.П. Гончар, М.А. (2007). Нечеткие методы кпастерного анализа в задачах автоматической классификации в экономике. Вісник Національного технічного університету України "Київський політехнічний інститут". Сер.: Інформатика, управління та обчислювальна техніка, 47, 198-206. Отримано $3 \mathrm{http}: / /$ nbuv.gov.ua/UJRN/Vkpi iuot 20074722

Лисовский, Н.Н. Халимов, Э.М. (2009). О классификации трудноизвлекаемых запасов. Вестник ЦКР Роснедра, 6, 33-35.

Максутов, Р., Орлов, Г., Осипов, А. (2005). Освоение запасов высоковязких нефтей в России. Технологии ТЭК, 6, 36-40.

Муспимов, Р. X (2016). Новая кпассификация запасов и ресурсов нефрти и горючих газов - движение вперед или вспять? Георесурсы, 18, 2,

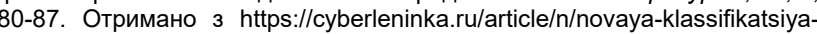
zapasov-i-resursov-nefti-i-goryuchih-gazov-dvizhenie-vpered-ili-vspyat

Нвизуг-Би, Л.К., Савенок, О.В. (2015). Трудноизвлекаемые запась углеводородов, важные ресурсы на территории Федеративной Республики. Материалы XXI Международной научно-практической конференции, современное состояние естественных и технических наук, Россия, Москва, декабрь 2015, 41-46. Отримано з https://cyberleninka.ru/ article/n/ekonomicheskaya-znachimost-razrabotki-osvoeniya-i-dobychibituma-iz-bituminoznogo-peska-i-tyazheloy-nefti-v-nigerii

Ященко, И.Г., Полищук Ю.М. (2016). Трудноизвлекаемые нести и анализ их свойств на основе классификации по качеству нефти. Вестник
Российской Академии естественных наук (Западно-Сибирское отделение), 19, 37-44.

Akhmetov, D.A., Efendiyev, G.M., Karazhanova, M.K., Koylibaev, B.N (2018). Classification of Hard-to-recover Hydrocarbon Reserves of Kazakhstan with the Use of Fuzzy Cluster-analysis. 13th International Conference on Application of Fuzzy Systems and Soft Computing, ICAFS 2018, 27-28 August 2018, Warsaw, Poland, 865-872.

Bezdek, J.C., Ehrlich, R., Full, W. (1984). FCM: The fuzzy c-means clustering algorithm. Computers \& Geosciences, 10, 2-3, 191-203.

Efendiyev, G.M., Mammadov, P.Z., Piriverdiyev I.A., Mammadov, V.N. (2018). Estimation of the lost circulation rate using fuzzy clustering of geological objects by petrophysical properties. Visnyk of Taras Shevchenko National University of Kyiv. Geology, 81, 2, 28-33.

Koilybayev, B.N., Strekov, A.S., Bissembayeva, K.T., Mammadov, P.Z., Akhmetov, D.A., Kirisenko, O.G. (2018). Decision-making on restriction of water inflows into oil wells in dependence on the type of initial information. 13th International Conference on Application of Fuzzy Systems and Soft Computing, ICAFS 2018, 27-28 August 2018, Warsaw, Poland, 859-864.

Sabeti, H., Javaherian, A. (2009). Seismic Facies Analysis Based on K-means Clustering Algorithm Using 3D Seismic Attributes. Shiraz 2009 - First International Petroleum Conference \& Exhibition, 4-6 May 2009, Iran, Shiraz. Отримано 3 https://www.researchgate.net/publication/286973601_Seismic_Facies_Analysis_ Based_on_K-means_Clustering_Algorithm_Using_3D_Seismic_Attributes

Zhang, L. (2015). Improvement of K-means algorithm and its applications in analysis of geological exploration seismic data. Electronic Journal of Geotechnical Engineering, 20, 12, 4423-4434.

\section{References}

Akhmetov, D.A., Efendiyev, G.M., Karazhanova, M.K., Koylibaev, B.N (2018). Classification of Hard-to-recover Hydrocarbon Reserves of Kazakhstan with the Use of Fuzzy Cluster-analysis. 13th International Conference on Application of Fuzzy Systems and Soft Computing, ICAFS 2018. 27-28 August 2018, Warsaw, Poland, 865-872.

Antoniadi, D.G., Savenyuk O.V. (2013). Analysis of the structure of hard-torecover reserves and growth trends. GeoEngineering, 18, 2, 76-80. [in Russian]

Bezdek, J.C., Ehrlich, R, Full, W. (1984). FCM: The fuzzy c-means clustering algorithm. Computers \& Geosciences, 10, 2--3, 191-203.

Dolynskiy, I. (2017) Geoinformation expert-modeling complex of research of regional models in geology. Visnyk of Taras Shevchenko National University of Kyiv. Geology, 79, 4, 86-91. [in Ukrainian]

Efendiyev, G.M., Mammadov, P.Z., Piriverdiyev I.A., Mammadov, V.N. (2018). Estimation of the lost circulation rate using fuzzy clustering of geological objects by petrophysical properties. Visnyk of Taras Shevchenko National University of Kyiv. Geology, 81, 2, 28-33.

Koilybayev, B.N., Strekov, A.S., Bissembayeva, K.T., Mammadov, P.Z., Akhmetov, D.A., Kirisenko, O.G. (2018). Decision-making on restriction of water inflows into oil wells in dependence on the type of initial information. 13th International Conference on Application of Fuzzy Systems and Soft Computing, ICAFS 2018, 27-28 August 2018, Warsaw, Poland, 859-864.

Lisovsky, N.N., Khalimov, E.M. (2009). On the classification of hard-torecover reserves. Bulletin of TsKR Rosnedra, 6, 33-35. [in Russian]

Maksutov, R., Orlov, G., Osipov, A. (2005). The development of highviscosity oil reserves in Russia. Energy Technologies, 6, 36-40. [in Russian]

Muslimov, R.H. (2016). New classification of reserves and resources of oil and combustible gases - moving forward or backwards? Georesources, 18, 2, 80-87. Retrieved from https://cyberleninka.ru/article/n/novaya-klassifikatsiya-zapasov-iresursov-nefti-i-goryuchih-gazov-dvizhenie-vpered-ili-vspyat [in Russian]

Nvizug-Bi, L.K., Savenok, O.V. (2015). Hard-to-recover hydrocarbon reserves, important resources in the territory of the Federal Republic of Nigeria. Proceedings of the XXI International Scientific and Practical Conference, current state of natural and technical sciences, 41-46. Retrieved from https://cyberleninka.ru/article/n/ekonomicheskaya-znachimost-razrabotkiosvoeniya-i-dobychi-bituma-iz-bituminoznogo-peska-i-tyazheloy-nefti-vnigerii [in Russian]

Sabeti, H., Javaherian, A. (2009). Seismic Facies Analysis Based on K-means Clustering Algorithm Using 3D Seismic Attributes. Shiraz 2009 - First International Petroleum Conference \& Exhibition, 4-6 May 2009, Iran, Shiraz. Retrieved from https://www.researchgate.net/publication/286973601_Seismic_Facies_Analysis_ Based on K-means Clustering Algorithm Using 3D Seismic Attributes

Vyzhva, S., Solovyov, I., Kruhlyk, V., Lisny, G. (2018). Prediction of high porosity zones in clay rocks at the eastern Ukraine. Visnyk of Taras Shevchenko National University of Kyiv. Geology, 80, 1, 33-39. [in Ukrainian]

Yashchenko, I.G., Polishchuk, Yu.M (2016). Hard-to-recover oils and analysis of their properties based on classification by oil quality. Bulletin of the Russian Academy of Natural Sciences (West-Siberian Branch), 19, 3744. [in Russian]

Zaichenko, Yu.P., Gonchar, M.A. (2007). Fuzzy cluster analysis methods in problems of automatic classification in the economy. News of the National Technical University of Ukraine "Kyiv Polytechnic Institute". Ser.: Informatics, control and obscuration technology, 47, 198-206. Retrieved from http://nbuv.gov.ua/UJRN/Vkpi_iuot_2007_47_22

Zhang, L. (2015). Improvement of K-means algorithm and its applications in analysis of geological exploration seismic data. Electronic Journal of Geotechnical Engineering, 20, 12, 4423-4434.

Надійшла до редколегії 17.05.19 
Г. Ефендієв', А-р техн. наук, проф., чл.-кор. НАНА,

E-mail: galib_2000@yahoo.com;

М. Каражанова², канд. техн. наук,

E-mail: mikado_70@inbox.ru;

Д. Ахметов ${ }^{2}$, докторант,

E-mail: aldee@list.ru;

І. Пірівердієв 1 , докторант,

E-mail: igorbaku@yandex.ru;

'Інститут нафти і газу Національної Академії Наук Азербайджану,

вул. Ф. Амірова, 9, м. Баку, AZ1000, Азербайджан;

${ }^{2}$ Каспійський державний університет технологій та інжинірингу ім. Ш. Есенова,

32 мікрорайон, м. Актау, 130003, Республіка Казахстан

\section{ОЦІНКА СТУПЕНЯ СКЛАДНОСТІ ВИЛУЧЕННЯ ВАЖКОВИДОБУВНИХ НАФТ НА ОСНОВІ ЇХНЬОЇ КЛАСИФІКАЦІЇ}

Розглянуто результати застосування кластерного аналізу при оцінці ступеня складності вилучення запасів нафти та його впливу на показник ефективності. 3 цією метою виконано кластеризацію із застосуванням алгоритму нечіткого кластер-аналізу. Слід зазначити, що поряд з родовищами важких і високов'язких нафт велика частка важковидобувних запасів приурочена також і до умов з дуже низькими значеннями проникності колекторів. Зібрані дані про в'язкості, густини нафти і проникність порід в умовах залягання нафт з різних родовищ Казахстану. За результатами даної класифікації проведено статистичний аналіз показників різних типів важковидобувних нафт. У процесі аналізу для кожного виділеного класу нафт визначалася узагальнена характеристика, що включає в'язкість, щільність нафти і проникність колекторів в умовах залягання. Узагальнена характеристика являє собою лінійне перетворення зазначених трьох характеристик. Результати були статистично оброблені. При цьому автори спробували встановити і проаналізувати взаємозв'язок між ступенем складності видобутку важковидобувних нафт і коефіцієнтом нафтовіддачі. У процесі аналізу розраховувалися середні значення коефіцієнта нафтовіддачі й показника ступеня складності видобутку важковидобувних нафт усередині кожного кластера і будувалася залежність між ними. Зазначена залежність, побудована по осереднених точках, близька до ступеневої, причому, як і слід було очікувати, зі збільшенням ступеня складності видобування нафти коефіцієнт нафтовіддачі падає. Отримані оцінки ступеня складності видобування нафти дозволяють ранжувати різні типи нафт за їхньою в'язкістю, щільністю і проникністю порід в умовах залягання, що можна використовувати для порівняння типів важковидобувних нафт за величиною показника якості. Методи розв'язання проблеми, пов'язаної з важковидобувними високов'язкими і важкими нафтами, повинні бути спрямовані на зниження в'язкості нафти у пласті: закачування гарячої води/пари у пласт, застосування електричних обігрівачів та ін.

Мета. Оцінка ступеня складності вилучення запасів і його впливу на ефективність розробки родовищ.

Методика. Рішення поставлених у роботі завдань здійснювалося методами математичної статистики і теорії нечітких множин. При цьому були використані: методика обробки результатів, кореляційний аналіз, а також алгоритм нечіткого кластер-аналізу.

Результати. У результаті досліджень отримано чотири класи запасів, кожен з яких характеризує ступінь складності вилучення запасів; запропоновано параметр для кількісної оцінки ступеня складності, що включає щільність і в'язкість нафти, проникність колекторів в умовах заляеання; отримано залежність між цим параметром і коефіцієнтом нафтовіддачі.

Наукова новизна. Виконано класифікацію важковидобувних запасів, засновану на нечіткому кластер-аналізі, запропоновано параметр для кількісної оцінки ступеня складності вилучення запасів; отримано залежність, що дозволяє оцінювати нафтовіддачу пласта за ступенем складності вилучення запасів.

Практична значимість. Отримані результати дозволяють провести класифікацію важковидобувних запасів і приймати рішення щодо вибору методів впливу на пласт у різних геологічних умовах.

Ключові слова: щільність, в'язкість, проникність, нечіткий кластер, важковидобувні запаси, ступінь складності вилучення, нафтовіддача.

Г. Эфендиев ${ }^{1}$, д-р техн. наук, проф., чл.-кор. НАНА,

E-mail: galib_2000@yahoo.com;

М. Каражанова ${ }^{2}$ К., канд. техн. наук,

E-mail: mikado_70@inbox.ru;

Д. Ахметов ${ }^{2}$, докторант,

E-mail: aldee@list.ru;

И. Пиривердиев ${ }^{1}$, докторант,

E-mail: igorbaku@yandex.ru;

${ }_{1}^{1}$ Институт нефти и газа Национальной Академии Наук Азербайджана,

ул. Ф. Амирова, г. Баку, 9AZ1000, Азербайджан;

Каспийский Государственный Университет технологий и инжиниринга им. Ш. Есенова,

32 микрорайон, г Актау, 130003, Республика Казахстан

\section{ОЦЕНКА СТЕПЕНИ СЛОЖНОСТИ ИЗВЛЕЧЕНИЯ ТРУДНОИЗВЛЕКАЕМЫХ НЕФТЕЙ НА ОСНОВЕ ИХ КЛАССИФИКАЦИИ}

Рассмотрены результаты применения кластерного анализа при оценке степени трудности извлечения запасов нефти и ее влияния на показатель эффективности. C этой иелью выполнена кластеризация с применением алгоритма нечеткого кластер-анализа. Следует отметить, что наряду с месторождениями тяжелых и высоковязких нефтей, большая доля трудноизлекаемых запасов приурочена также и к тить, что наряду с месторождениями тяжелых и высоковязких нефтей, большая доля трудноизлекаемых запасов приурочена также и к условиях залегания нефтей из различных месторождений Казахстана. На основе результатов данной классификации проведен статистический анализ показателей различных типов трудноизвлекаемых нефтей. В процессе анализа для каждого выделенного класса нефтей определялась обобщенная характеристика, включающая вязкость, плотность нефти и проницаемость коллекторов в условиях залегания. Обобщенная характеристика представляет собой линейное преобразование отмеченных трех характеристик. Результаты были статистически обработаны. При этом авторами сделана попытка установления и анализа взаимосвязи между степенью сложности добычи трудноизялекаемых нефтей и коэффициентом нефтеотдачи. В процессе анализа рассчитывались средние значения коэффициента нефтеотдачи и показателя степени сложности добычи трудноизвлекаемой нефти внутри каждого кластера и строилась зависимость между ними. Данная зависимость, построенная по усредненным точкам, близка к степенной, причем, как и следовало ожидать, с увеличением степени сложности извлечения нефти коэффициент нефтеотдачи падает. Полученные оценки степени сложности извлечения нефти позволяют ранжировать разные типы нефтей по их вязкости, плотности и проницаемости пород в условиях залегания, что можно использовать для сравнения типов трудноизвлекаемых нефтей по величине показателя качества. Методы решения проблемы, связанной с трудноизвлекаемыми высоковязкими и тяжелыми нефтями, должны быть направлены на снижение вязкости нефти в пласте: закачка горячей воды/пара в пласт, применение электрических обогревателей и др.

Цель. Оценка степени сложности извлечения запасов и ее влияния на эффективность разработки месторождений.

Методика. Решение поставленных в работе задач осуществлялось при помощи методов математической статистики и теории нечетких множеств. При этом были использованы: методика обработки результатов, корреляционный анализ, а также алгоритм нечеткого кластер-анализа.

Результаты. В результате исследований получены четыре класса запасов, каждый из которых характеризует степень сложности извлечения запасов; предложен параметр для количественной оценки степени сложности, включающий плотность и вязкость нефти, проницаемость коллекторов в условиях залегания, получена зависимость между этим параметром и коэффициентом нефтеотдачи.

Научная новизна. Выполнена классификация трудноизвлекаемых запасов, основанная на нечетком кластер-анализе, и предложен параметр для количественной оценки степени сложности извлечения запасов; получена зависимость, позволяющая судить о нефтеотдаче пласта по степени сложности извлечения запасов.

Практическая значимость. Полученные результаты позволяют провести классификацию трудноизвлекаемых запасов и принимать решения по выбору методов воздействия на пласт в различных геологических условиях.

Ключевые слова: плотность, вязкость, проницаемость, нечеткий кластер, трудноизлекаемые запасы, степень сложности извлечения, нефтеотдача. 